\title{
材端に設置された木質鋼板単体ボルト接合の繊維直角方向荷重 に対する強度算定法の提案
A STRENGTH CALCULATION METHOD OF SINGLE BOLTED TIMBER JOINT FOR END MEMBER JOINT LOADED PERPENDICULAR TO THE GRAIN

\author{
野口昌宏*, 坂田弘安**, 和田章***, 宮澤健二**** \\ Masahiro NOGUCHI, Hiroyasu SAKATA, Akira WADA \\ and Kenji MIYAZAWA
}

\begin{abstract}
We, in this article, propose a manual strength calculation method of single bolted timber joint for end member joint loaded perpendicular to the grain. The strength calculation method takes into account the edge distance, the end distance, and the slenderness ratio as the parameters. The validity of the proposed calculation method was confirmed by the experimental results, edge distance of $1 d \cdot 2 d \cdot 4 d \cdot 6 d \cdot 7 d$, end distance of $1 d \cdot 2.5 d \cdot 4 d \cdot 7 d \cdot 10 d$, slenderness ratio of $3.75 d \cdot 7.5 d \cdot 10 d$.
\end{abstract}

Keywords : STRENGTH CALCULATION METHOD, BOLTED TIMBER JOINT, PERPENDICULAR TO THE GRAIN 強度算定法、ボルト接合、繊維直角方向

1. はじめに

木質構造では接合部の強度が、その部材の強度を超える保有耐力 接合や全強設計は困難である。そのため、接合部の力学的性質が構 造物全体の力学性能に大きく影響し, 木質ラーメン構造や集成材構 造では構造物全体の終局強度は接合部の終局強度で決まることが多 い。実際の接合部は複数のファスナーで構成される場合が多いが、 それらのメカニズムを把握するためにも、その基礎となる単体のボ ルト接合についての割裂破壊メカニズム把握が必要と考え、単体の ボルトに焦点を当てて以下議論する。

木質構造の接合部は母材である木質材料の割裂やせん断破壊に起 因して破壊する。しかし、木質材料の割裂やせん断破壊は未解明な 部分が多く、一般的なボルトを用いた接合部でさえ実験なしには最 大耐力を知ることができないとされてきた。しかし、2006 年度の日 本建築学会木質構造設計規準の改正で、初めてボルトやドリフトピ ンなどのダボ型接合の終局耐力算定法が示された ${ }^{1)}$ 。その算定法の 基本式はvan der Put and Lei jten の研究 ${ }^{2)}$ に基づいたものである。 日本建築学会木質構造設計規準を用いると、繊維直角方向に負荷を 受けるダボ型接合で、端距離が直径の 7 倍以上 $(7 d)$ 且つ、縁距離 が直径の 4 倍以上確保された場合、算定することが出来る。

日本建築学会木質構造設計規準ではvan der Put らの研究に基づ く割裂算定式を用いており、この式の適応範囲等に対して研究を行 うことは重要であると考えている。ボルト接合の最大強度は縁距離

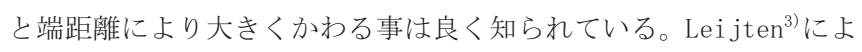
ると、Van der Put らの割裂強度算定式の適応範囲は、端距離が充
分に大きい事とされている。しかし、具体的に端距離がいくら必 要なのかは示されていない。Jensen ${ }^{4)}$ が指摘しているように、クラ ックの定義や扱いに不明瞭な部分が確かにある。モデル化の初めで はクラックが充分長いことを前提に展開しているが、簡略化のため クラックが充分小さいという扱いに切り替わる部分が不明瞭である。 クラックの定義や扱いが不明瞭な部分があるため、物理的意味から の適応範囲の導出をしなかったのであろう。Van der Put らの提案 式は、最終的には材中央に設置したボルト接合の実験結果から材料 定数を決めて, 端距離が十分大きい場合を適応範囲とした半実験式 の立場をとっている。理論的に適応範囲を決定できなければ、適応 範囲は材料定数を決めた実験での縁距離以上とる事は最低条件であ ろう。国内の樹種について材料定数を決めた安村らの実験は、一般 と比べて約 1.7 倍の端距離（直径の 12 倍）で行っている ${ }^{5) 。 し た か ゙ ~}$ って、常に両側の端距離が十分確保できる材中央に設置する接合部 に限定すべきと考えられる。材端に設置する接合部は、別途算定法 を設けるべきであると考えている。そこで本論文では、材端に設置 する接合部を対象として、1 本の木質ボルト接合の最大強度の 1 つ の算定法を提案する。

なお、木質ボル卜接合部の配置の規制（縁距離や端距離、ボル卜 間隔等）が厳しいために、要求性能を満たすために規制以下の配置 で新しい接合部を開発する場合が多くそれらの知見も必要との立場 で、日本建築学会木質構造設計規準以下の端距離・縁距離をも含め て扱う。本論文では、1 本の木質ボルト接合の最大強度の 1 つの算 定法を提案し、実験により妥当性を確認する。この破壊力学に基づ

\footnotetext{
* 秋田県立大学木材高度加工研究所 流動研究員 - 農博

** 東京工業大学建築物理研究センター 准教授・工博

*** 東京工業大学建築物理研究センター 教授・工博

**** 工学院大学建築学科 教授. 工博
}

Postdoctoral Fellow, Institute of Wood Technology, Akita Prefectural University, Dr. Agr. Assoc. Prof., S.E.R.C., Tokyo Institute of Technology, Dr. Eng.

Prof., S.E.R.C., Tokyo Institute of Technology, Dr. Eng.

Prof., Dept. of Architecture, Faculty of Engineering, Kogakuin University, Dr. Eng. 
いた強度算定法は、ボルトのような径長比が 10 程度までの比較的短 い場合についてであり、YET 式とは全く異なった考え方である。

第 2 章では、1 本の木質ボルト接合の最大強度の 1 つの算定法 を誘導する。第 3 章では、実験方法について説明する。第 4 章では、 実験結果を用いて提案算定法の妥当性を検証する。

\section{2. 算定式の導出}

\section{1 算定式導出の基本方針}

本論文ではボルト接合の破壊モードを考慮して、割裂やせん断で 材を 2 つに分離するような破壊を生じる面を想定し、その面を破壊 面と定義した。そして、力学モデル化を行いそれに基づき算定式を 導出した。破壊をモデル化する場合は破壊形態の考察からはじめる のが定石のように思われるが, 実験時の破壊形態観察では、割裂破 壞の違いの分類は出来なかった。そこで、力学的に考えて破壊面に 作用寸ると考えられる全ての応力に対して割裂破壊が生じると仮定 しモデル化した(図 1)。なお、手計算可能な算定式の導出が目的で ある。そして，それぞれの応力で割裂またはせん断破壊すると仮定 した場合の強度算定式を導出した。最後に, 接合部の破壊機構を考 え，接合部の破壊強度算定式を導出した。

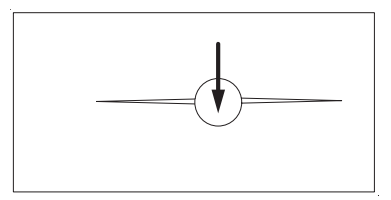

(a) 局所的な応力集中による割裂

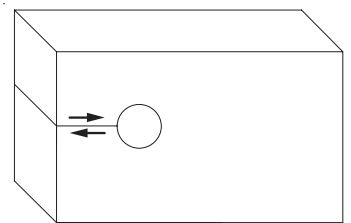

（c）せん断破壊

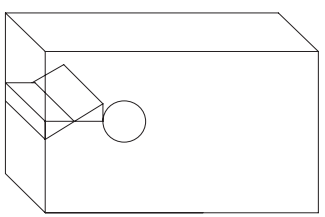

（b）曲げモーメントによる割裂

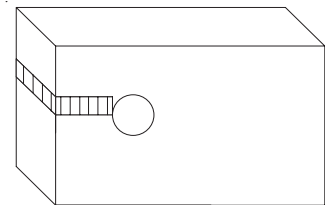

(d) 引張力による割裂
図 1 破壊の想定

簡易のために以下の仮定を設けた。ボルト穴は円形で割裂やめり 込み等の損傷は一切無い状態を想定した。また，幅方向に対しては 一様と仮定した。図2(b)に示すように本来は円形のボルト穴を正方 形として扱った。辺の長さはボルトの直径と同一の $d$ とした。

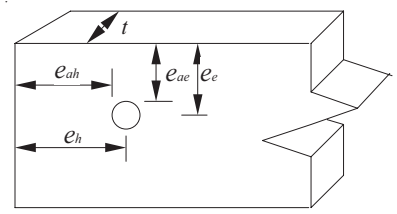

（a）想定したボルト接合

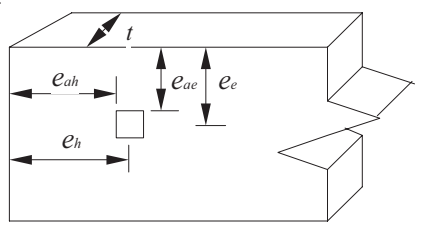

（b）簡易モデル化
図 2 想定したボルト接合とその簡易モデル化

破壊について考える。部材を $2 つ に$ 割る割裂およびせん断破壊を、 割れが入った後に耐力を保持できるケースと耐力を保持できない久 一スの 2 つに分類した。そして、その 2 つのースには、それぞれ 別の破壊クライテリアを用いた。前者は、加力点から反力点まで力 が流れるルートにおいて力を伝えきれずに割裂破壊をしてしまう場 合で、割れが生じた時点で耐力がほぼゼロに低下し、ボルト接合の
破壊に至るケースを想定した。作用する応力が材料強度に達した時 点を破壊と定義した。後者は、加力部の局所的な応力集中による割 裂破壊で、局所的な集中応力により小さな割れが生じても局所的な 応力集中部以外の作用応力や破壊面全体に作用寸る応力は小さくそ れだけでは接合部の崩壊（破壊）機構が形成されず接合部の耐力低 下は小さい。割れが大きく進展すると急激な耐力低下が生じボルト 接合の破壊に至ると想定した。破壊の定義は破壊力学を用いた。

\section{2 加力部付近の局所的な応力集中による割裂破壊強度算定式の誘導}

\section{2.1 破壊の定義とモデル化の流れ}

破壊力学は、van der Put ${ }^{1}$ 、Yasumura ${ }^{6}$ ら、 Jensen ${ }^{4}$ の接合部の接合 部、Peterson、の切久きをもつ梁および湾曲集成材 ${ }^{7}$ 、Gustafssen の 切欠きをもつ梁 ${ }^{8}$ に対して木材の破壊モデルで採用している破壊ク ライテリア「ポテンシャルエネルギーの減少分（＝外部仕事の減少 分）がある基準（破壊エネルギー）に達した時、破壊と仮定する」 を用いた。すなわち、割裂破壊のクライテリアは式(1)と定義した。

$$
G_{c}=-\frac{d W}{t d \beta} \ldots(1)
$$

ただし、 $\Delta W=P \cdot \delta_{1}-P \cdot \delta_{2}=P \cdot\left(\delta_{1}-\delta_{2}\right), \quad P$ : 加力点の荷重、 $\delta_{1}:$ 割 れが進展する前の加力点での変位、 $\delta_{2}$ : 割れが $\Delta \beta$ 進展した後の加力 点での変位、 $\beta$ : クラック長さ

\subsection{2 モデル化の方針と流れ}

具体的作業の大きな流れを以下に簡潔に示す。

(1)初期状態および割れが $\Delta \beta$ 進展した状態を想定する

(2)初期状態および初期状態から割れが $\Delta \beta$ 進展した状態のモデル 化を行い、 $P$ が働く位置での変形を算出する。

(3)初期状態および割れが $\Delta \beta$ 進展した状態のそれぞれについて、 力 $P$ がな寸仕事を求める

(4)「(仕事) $=($ エネルギー)」の関係を用いて、「(割れが $\Delta \beta$ 進展し た場合のポテンシャルエネルギーの減少分 $)=($ 初期状態で $P$ がな寸仕 事) 一(割れが $\Delta \beta$ 進展した状態で $P$ がな寸仕事)」と考えた。

(5)破壞は「(ポテンシャルエネルギーの減少分) $=$ (破壊エネルギ 一)」の関係より、力の限界值を求めた。

（ただし，次節のモデル化に際しては(4)(5)同時に計算した。) ボルト穴は円形で割裂が入っておらず、損傷も一切無い状態を想 定し，等価梁置換法を用いてモデル化した。等価梁置換の考え方に ついて既往の van der Put モデルと比較しながら以下に議論する。

Van der Put らのモデルでは、割れが入り 2 つに分離した部材の それぞれの曲げおよびせん断変形を算出し、負担側の加力点の変位 から非負担側の加力位置の変位を引くことにより相対変位を求める。 その後、割れが入っていない場合の加力点の変位を計算し、それら からエネルギーのコンプライアンスを求める流れとなっている。つ まり、終局強度算定寸る際に、加力負担側の縁距離と材のせいの比 が重要な因子となる。このことは、加力負担部の長さが非負担部の 長さに比べて著しく小さいとき、ほとんど耐力が出ないという実験 的事実により検証されており、木質構造設計規準にも古くから同様 の記述が注意事項として書かれている。しかし、本論文では材端に 設置する接合部を対象にしているので、エネルギーのコンプライア ンスを求める際に、非負担側の加力位置の変位がゼロと仮定し、負 担側の加力点の絶対変位を用いる。なお、この仮定は、Van der Put らのモデルより常に若干安全側の評価となる。構造要素としての接 合部、接合部の構成の 2 点から材端接合と材中央接合の特性を比較 
しながら以下に材端接合に必要な条件を議論する。

まず、構造要素としての接合部の観点から、材端に設置する接合 部と材中央に設置する接合部の特性を考える。材中央に設置する接 合部の例は、大梁一梁接合での大梁、トラス材一弦材接合での弦材 等で、一般的に長期荷重を受ける場合が多く、最大耐力よりクリー プなどの長期性能が重要な場合が多い。一方、材端に設置する接合 部の例は、柱勝ちのモーメント抵抗接合での梁、柱脚接合等で、一 般的に地震時に動的な荷重を受ける部材を用いる場合が多く、接合 部の強度は地震エネルギー吸収や終局強度など構造物全体の耐震性 能を左右する因子になる場合が多い。つまり、地震荷重などの不確 定要素を含む荷重が作用するため、安全側に評価するモデルである ベきと考えた。

つぎに、接合部の構成の観点から、材端に設置する接合部と材中 央に設置する接合部の特性を考える。材端接合には、モーメントに も抵抗させる接合もあり、複数のボルトを配置して構成する場合が 多い。そのため、設置位置により強度を変えるのではなく、できる 限り簡易化するべきと考えた。つまり、材端に設置する接合部を想 定した場合、簡易化と動的効果が分からないため、安全側に評価寸 るモデルであるべきと考え、負担側の加力点の絶対変位を用いた。

\subsection{3 算定式の導出}

まず、割れが進展する前の加力部の変形を考える。図 3 に初期状 態の想定モデルとそれに基づいた力学モデルを示す。初期状態は、 亀裂長さ $(\beta \rightarrow 0)$ の亀裂が存在すると仮定する。図 3 に示すように 幾何学的関係から等価な両端固定の梁の曲げ及びせん断変形を考慮 すると、割れが進展する前の荷重位置での変位は式(2)で表せる。た だし, 右辺の第一項は曲げによる変位を, 右辺の第二項はせん断に よる変位を表わしている。

$$
\delta_{1}=\frac{(d / 2)^{3} P}{12 E I}+\frac{\kappa P 0.5 d}{G e_{a e} t} .
$$

ただし、 $d$ : ボルトの直系、 $I$ : 等価梁置換した場合の断面二次モー メント、 $E$ : ヤング係数、 $e_{a e}$ : 縁あき、 $t$ : 材はば、

次に、割れが $\Delta \beta$ だけ進展した場合の加力部の変形を考える。図 4 に割れが $\Delta \beta$ 進展した時の想定モデルとそれに基づく力学モデル を示す。なお，ボルトはめり込まないと仮定した。割れの進展は、 加力側に割れが $\Delta \beta$ 入るがボルトの木材の繊維方向に対する位置は 変化しないと考え、図 4 に示すように集中荷重を作用させる座標位 置は割れが入る前のモデルと同一とした。この場合も同様に、図 4 の中に示寸幾何学的関係から等価な両端固定の梁の曲げ変形とせん 断変形を考慮すると、割れが $\Delta \beta$ だけ進展した場合の加力部の変形 は式(3)として表せる。

$$
\delta_{2}=\frac{(d / 2+\Delta \beta)^{3} P}{12 E I}+\frac{\kappa P(0.5 d+\Delta \beta)}{G e_{a e} t} .
$$
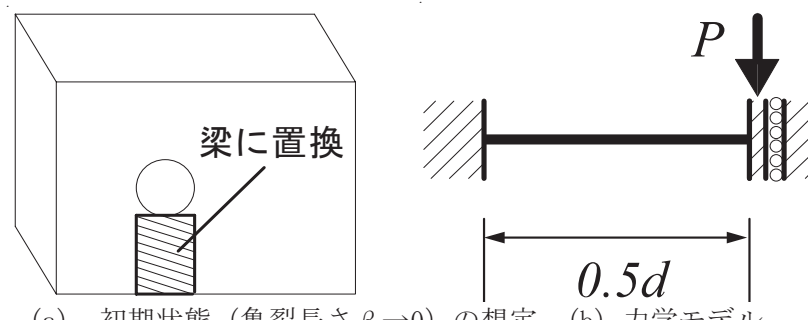

（a）初期状態（亀裂長さ $\beta \rightarrow 0 ）$ の想定 $\quad($ b ) 力学モデル 図 3 初期状態の想定モデルとその力学モデル

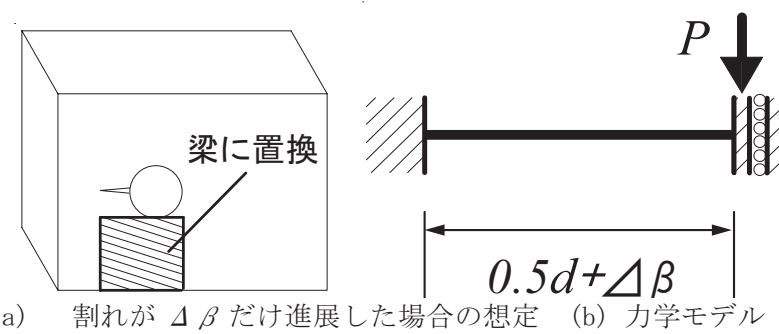

図 4 割れが $\Delta \beta$ 進展した場合の想定モデルとその力学モデル

式(2)、(3)を用いて式(1)のただし書きを用いて $\Delta \mathrm{W}$ を求め、 $\Delta \mathrm{W}$ を式 (1)に代入して、右辺を $\beta$ で積分し、 $P$ について整理することで、この破壊 モードでのボルト接合の耐力算定式を式(4)として導出した。ただし、 $G_{c}$ は エネルギー開放率、 $I=t e_{a e} / 12$ を用いた。

$$
P=2 t \sqrt{\frac{2 G_{c}}{\frac{0.75(d+2 \Delta \beta)^{2}}{E e_{a e}{ }^{3}}+\frac{\kappa}{G e_{a e}}}}
$$

ここで、式（4）はボルト単体の強度算定法としては、複雑であると 考えた。確かに、木質構造設計規準 1)では、EYT 式を採用されてい るが、計画や基本設計時に使うのは大変であり、著者らは Trayer の実験式 ${ }^{9)}$ などをもう一度見直して算定式を簡易化すべきと考えて いる。式（4）の誘導過程で、曲げ変形とせん断変形を考慮したが、 幾何学的にせん断変形が卓越すると考えられる。そこで、曲げ変形 が無視できると仮定し、式（2）及び式（3）それぞれの右辺の第一 項を省略すれば、この破壊モードでのボルト接合の耐力算定式を式 (5)として導出できる。

$$
P_{1}=2 t \sqrt{\frac{2 G_{c} G e_{a e}}{\kappa}}=2 t \sqrt{\frac{2 G_{c} G e_{a e}}{1.2}}=2 t \sqrt{1.67 G_{c} G e_{a e}}
$$

図 5 に式（4）と式（5）の算定值の関係、図 6 に $\beta$ と式（4）と 式 (5) の算定值の比を示す。ボルトは M $3,8,12,16,20,24$ の 6 条件、 縁距離は $1 d$ から $15 d$ までの 15 条件、 $\beta$ は 0.2 から $20 \mathrm{~mm}$ の 10 条 件、Gc は 100、200、220、300 N/m の 4 条件、で合計 3600 条件につ いてパラメータスタディを行った。式(4) と式(5) は共に $\mathrm{t}$ に比例す るため、 $t$ による影響はないと考え、幅方向は径長比は全て 1 とし た。ヤング係数 $E$ とせん断弾性係数 $G$ は、スギを想定して 2.5 節に 示す值を用いた。なお、鋼板添え板接合を想定した。これらの結果 から、パラメータスタディで用いた範囲内では、式(4)を式（5）に 置き換えることは可能と考えられる。

\section{3 破壊面に作用する応力の考え方}

これらの破壊モードでは、割れが生じた瞬間に耐力がほぼゼロに 低下し、ボルト接合の破壊に至るケースを想定した。

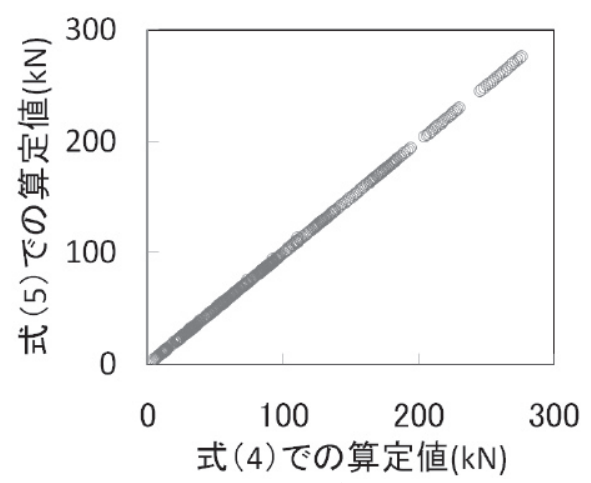

図 5 式(4) と式(5)の算定值の関係 


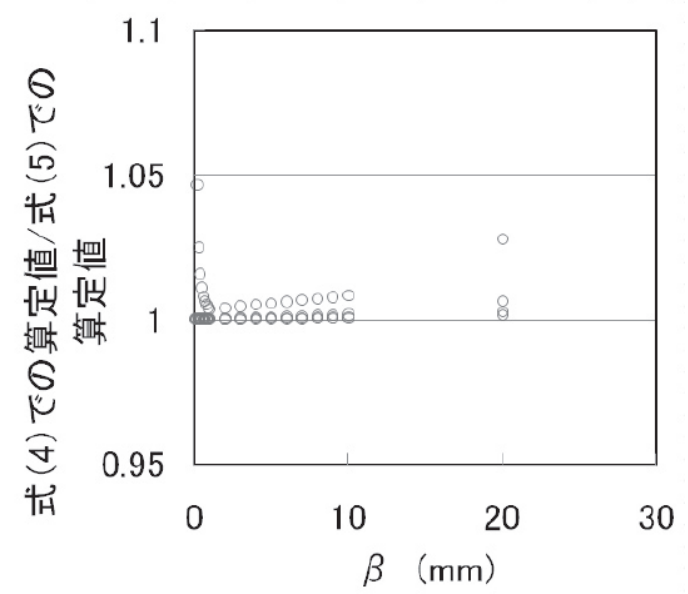

図 $6 \quad \beta$ と式(4) と式(5)の比

\section{3. 1 破壊面に生じる曲げモーメントによる割裂破壊}

まず、作用応力について考える。図 7 にボルト接合の想定する力 の流れとそのブロック分割置換モデルを示す。図 7 の (a) の破線で示 す岡体部は、各部を梁と考えた場合に断面性状が大変大きくなる、 または、剛体部と弾性体部の界面での境界条件が対称条件となるこ とから、破線で示寸部分を剛体として扱い、（b）に示すように界面 での境界条件を全体性状を考慮して決めることで、力学モデル化を 表現する方針をとった。図 7 の（b）に示すように剛体部と弾性体 部の界面での境界条件をモデル化した。ボルトの中心から材軸の中 心までの距離 $L_{1}$ は, 図 7 (b) に示寸幾何学的条件から式 (6) で表わ される。

$$
L_{1}=\frac{d}{2}+\frac{e_{h}-0.5 d}{2}
$$

ただし、 $d$ : ボルトの直径, $e_{h}$ : 端距離

また, 破壊想定面に発生するモーメント $M$ は, 図 7 に示す境界条件から, 構造力学的に, ボルトが木材に加える力 $P$ と $L_{1}$ を用いて式(7)で表わさ れる。

$$
M=\frac{P}{2} \times L_{1} \ldots(7)
$$

次に有効断面を考える。具体的なモデル化を図 6 に示す。この場 合の有効面積は、端あき $e_{a h}$ と材の幅 $t$ の積である。

$$
Z=\frac{t e_{a h}^{2}}{6} \ldots(8)
$$

梁の平面保持の仮定を用いると、図 7 に示寸有効断面の断面係数 $Z$ と横引っ張り強度 $\sigma_{90}$ 及び破壞想定面に発生するモーメント $M$ は式(9) の関係に従う。

$$
\sigma_{90}=\frac{M}{Z}
$$

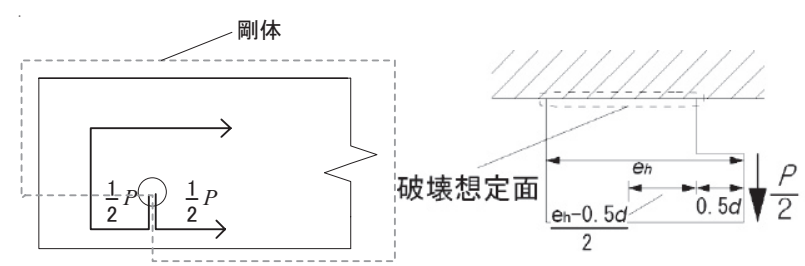

（a）ボル卜接合の想定する力の流れ （b）ブロック分割置換モデル

図 7 ボル卜接合の想定する力の流れとそのブロック分割置換モデル

式(7)、式(8)、式(9)より、この破壊モードでのボル卜接合の耐力算定 式を式(10)として導出した。

$$
P_{2}=\frac{2 t e_{a h}{ }^{2} \sigma_{90}}{3 e_{h}+1.5 d}
$$

\subsection{2 破壊面に生じるせん断力によるせん断破壊}

まず、作用応力について考える。図 8 にボルト接合の想定する力 の流れとそのブロック分割置換モデルを示す。図 8 の(a)の点線で示 す剛体部は、各部を梁と考えた場合に断面性状が大変大きくなる、 または、剛体部と弾性体部の界面での境界条件が対称条件となるこ とから、点線で示寸部分を剛体として扱い、（b）や（c）に示すよ うに界面での境界条件を、全体正常を考慮して決めることで、力学 モデル化を表現する方針をとった。図 8 の（b）に示すように剛体 部之弾性体部の界面での境界条件は厳密には対称条件にす心゙きであ るが、全体の寸法を考えた上では、この部分の曲げ剛性は小さくピ ンのようになると考えられる。そこで、図 8 の (c)のようにモデル 化した。破壊面に対して一様にせん断応力が作用すると仮定と有 効面積は、端あき $e_{a h}$ と材の幅 $t$ の積となる。この有効面積にせん断 強度を乗じることで、この破壊モードでのボルト接合の耐力算定式 を式(11)として導出した。

$$
P_{4}=2 e_{a h} t \tau \ldots(11)
$$

\section{3.3 破壊面に生じる引張力による割裂破壊}

図 7 及び図 8 のどちらのケースに対しても破壊面に対して、一様 に $P / 2$ の引張り応力が作用すると仮定する。そうすると有効面積は、 端あき $e_{a h}$ と材の幅 $t$ の積となる。この有効面積に横引つ張り強度 を乗じることで、この破壊モードでのボルト接合の耐力算定式を式 (12)として導出した。

$$
P_{3}=2 e_{a h} t \sigma_{90}
$$

\section{4 単体木質ボルト接合の破壊機構}

本研究で対象にしている材端接合の場合、接合部の端距離として 考慮しなければならないのは，そのボルトから見て材端側の端距離 だけであり、他側の端距離はボル卜直径の 100〜200 倍以上と十分の 端距離を有している。この特徴を甘味した上で，接合部の破壊機構 を考える。

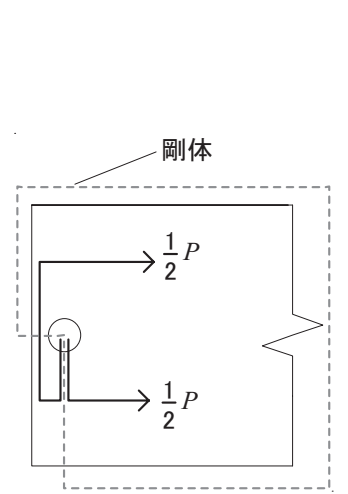

(a) 力の流れの想定

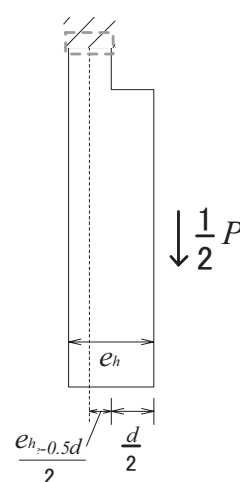

(b) モデル化

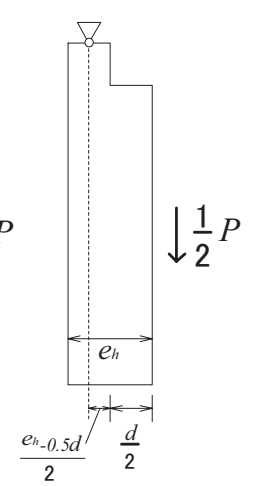

（c）モデルの簡易化 図 8 ボルト接合の想定する力の流れとそのブロック分割置換モデル

\section{4.1 木部のせん断で破壊する場合の崩壊機構の想定}

ボルトから見て材端側でせん断破壊を起こした場合を考える。こ のモードの特徵は, 荷重と直交方向の応力成分で材端部が破壞する 事である。接合部の破壞（崩壊）機構が形成されるためには，材中 央側でのせん断破壊が必要である。材中央側でのせん断面積は極め て大きいため材中央側でのせん断破壊は生じないと考えた。つまり， 
材端側でせん断破壊を起こした場合、せん断破壞で崩壊メカニズム が生じることなく荷重低下が起こらない。そのために, 応力再配分 が起こり、材端側の耐力抵抗機能が無くなるが、材中央側（片側） の割裂で破壊に至る。

\section{4.2 木部の横引張りで破壊する場合の崩壊機構の想定}

ボルトから見て材端側で横引張りで破壊を起こした場合を考える。 その時点で, 破壊想定面全てが離れる。破壊想定面全てが離れると, 材端側は全ての応力（引張り, せん断, 曲げ) が伝えられなくなる。 この時点で接合部の破壊 (崩壊) 機構が形成され, 瞬時に耐力低下 を起こすと考えられる。したがって, このケースでは, ボルト側か ら見て材中央側が耐力負担出来ず, 応力の再配分がおこらないと考 えた。

\section{4.3 木部の曲げモーメントで破壊する場合の崩壊機構の想定}

ボルトから見て材端側で横引張りでの破壊を考える。その時点で, 破壞想定面での危険断面のみが離れる。危険断面のみが離れると， 材端側はこれ以上耐力上昇は出来ない。しかし，この時点では接合 部の破壊（崩壊）機構が形成されず, 瞬時に耐力低下を起こすので はなく, 徐々に耐力低下していくと考えられる。したがって, この ケースでは, ボルト側から見て材中央側が耐力負担出来, 応力の再 配分がおこると考えた。

\section{4.4 加力部付近の局所的な応力集中で割裂破壊する場合の崩壊機構の想定}

ボルトから見て材端側で加力部付近の局所的な応力集中での割裂 破壞を考える。十分な端距離を有する場合、材端側および材中央側 共に同時に割裂が入ると考えられ、両側の割裂破壊強度を足し合わ せが出来ると考える。

\section{4.5 十分な端距離を有すると仮定した場合の崩壊機構の想定}

材端側および材中央側共に同時に割裂が入ると考えるため、両側 の割裂破壊強度を足し合わせが出来ると考える。その瞬間、材中央 側が負担できるため応力の再配分が起こり、耐力低下を伴わず、材 中央側だけの耐力を負担出来る。

\section{4.6 接合部の強度}

本報告では、曲げ応力による割裂破壊と引張応力による割裂破壊 で決まる場合については、それらの值が加力部の局所的な応力集中 による割裂破壊の片側分に満たない場合は加力部の局所的な応力集 中による割裂破壊で求まる強度の半分とした。2.4.1 から 2.4 .5 まで の接合部の崩壊機構を下式でまとめ表わす。

$$
\begin{gathered}
P=\min \left(P_{l}, \quad P_{3}, \quad \max \left(\min \left(P_{2}, \quad P_{4}\right), \quad 0.5 P_{l}\right)\right) \ldots(13) \\
P_{1}=2 t \sqrt{1.67 G_{c} G e_{a e}} \quad P_{2}=\frac{2 t e_{a h}{ }^{2} \sigma_{90}}{3 e_{h}+1.5 d} \quad P_{3}=2 e_{a h} t \sigma_{90} \quad P_{4}=2 e_{a h} t \tau
\end{gathered}
$$

ただし、 $\rho$ : 密度、 $G$ : せん断弾性係数、 $\sigma_{90}$ : 横引っ張り強度、 $\tau$ : せん断強 度、 $e_{e}$ : 縁距離、 $e_{h}$ : 端距離、 $t$ : 材幅、 $e_{a e}$ : 縁あき、 $e_{a h}$ : 端あき

\section{5 計算に用いた材料定数}

JIS の木材試験法に準じてせん断実験を行った結果、8MPa が得られ た。また、 3 点曲げの横引っ張り試験を行った結果 $2.2 \mathrm{MPa}$ の值が得られ た。ヤング係数 $E$ は $6.5 \mathrm{GPa}$ 、せん断弾性係数は AIJ 規準に準じて $\mathrm{E} / 15$ を用いた。んは形状係数で 1.2 とした。エネルギー開放率 $G_{c}$ は式 $\left.(14)^{6}\right)$ から算定し、 $212 \mathrm{~N} / \mathrm{m}$ を用いた。

$$
G_{f}=-162+1.07 \rho
$$

\section{3. 検証実験}

ボル卜接合部の(端距離: $1 d, 2 d, 4 d, 6 d, 7 d$ 、縁距離: $1 d, 2.5 d$, $4 d, 7 d, 10 d$ 、径長比: $3.75 d, 7.5 d, 10 d$ と変化させ実験を行った。

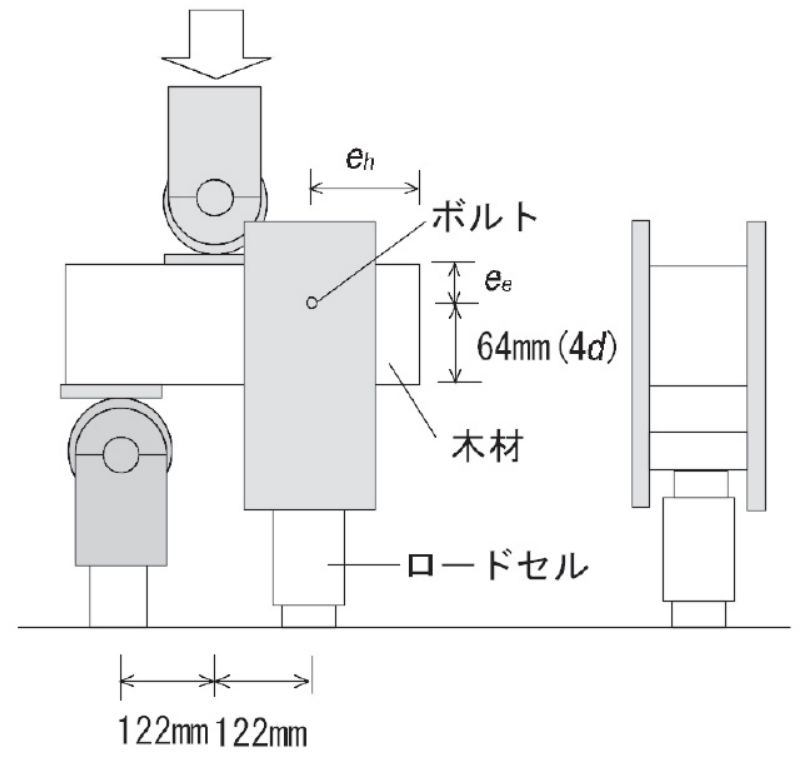

図 9 試験ジグ

E65 のスギ集成材を用いた。ボルトは直径 16（M16）で SS400 とした。 各条件 2 体ずつ、合計 160 体行った。試験概要を図 9 に示す。加力は、 単調加力で行った。変位の計測は、添え板鋼板と木材との相対変位をこ の接合部のすべり量とした。

\section{4. 実験結果による提案式の妥当性の検討}

図 10 に横軸を縁距離としてまとめなおした実験結果と提案算定式 の計算值を示す。実験值は実験によって得られた最大耐力を示す。 理論計算值は式 (13) で算出した。なお、端距離 0 から $0.5 d$ までは、 端あきが 0 となり、式(13)の $P_{3}$ 及び $P_{4}$ 共に 0 となる。 $0.5 d$ から立ち 上がる最初の勾配は、横引っ張り破壊 $\left(P_{3}\right)$ で決定し、2 番目の勾 配は材中央側の割裂破壊（ $0.5 P_{I} ）$ で決まり、3 番目の曲げモーメン 卜によるの割裂破壊 $\left(0 P_{2}\right)$ で決定し、最後の勾配は加力部付近の局 所的な応力集中による割裂破壊 $\left(P_{1}\right)$ で決定した。本報告で提案し た算定式が、実験結果をある程度の精度で推定できることが分かっ た。ただし、端距離が $1 d$ の場合は適応性が悪い。

図 11 に横軸を端距離としてまとめなおした実験結果と提案算定式 の計算值を示す。実験值は実験によって得られた最大耐力を示す。 理論計算值は式（13）で算出した。本報告で提案した算定式が、実 験結果をある程度の精度で推定できることが分かった。ただし、縁 距離が $1 d$ の場合は適応性が悪い。図 12 に横軸を径長比としてまと めなおした実験結果と提案算定式の計算值を示す。実験值は実験に よって得られた最大耐力を示す。理論計算値は式 (13)で算出した。 また、比較のため、EYT 式での算定值も示す。本報告で提案した算 定式が、実験結果をある程度の精度で推定できることが分かった。

図 13 の(a)に実験での寸べての条件での実験值と算定值の比較を示 す。これをみると、ばらつきが大きくばらつき係数として 0.5 を採 用してもばらつきをとらえる事が出来ない。

図 13 の(b)に実験で端距離及び縁距離が $1 d$ の場合を除いた条件で 

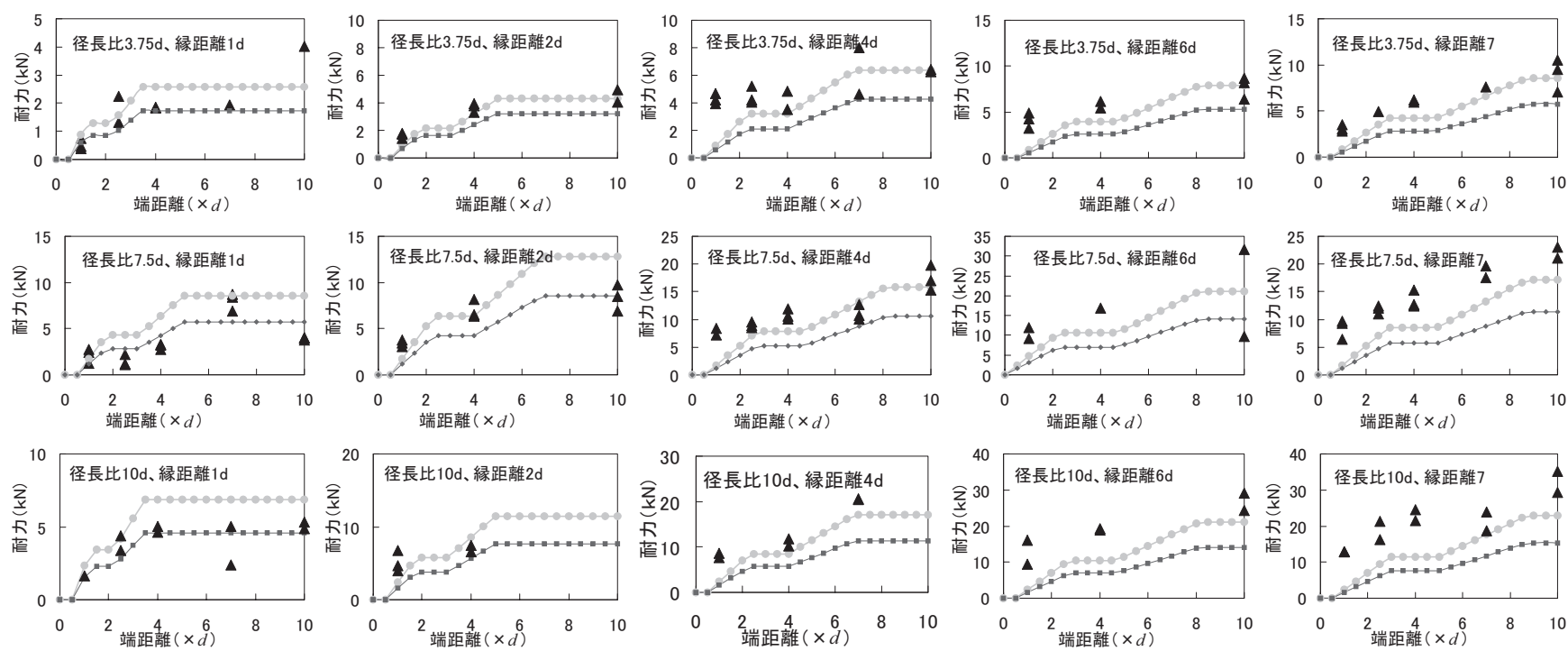

図 10 横軸を縁距離としてまとめなおした実験結果と提案算定式の計算值

ただし、ム：実験值、上側の線：算定值、下側の線：算定值の $2 / 3$
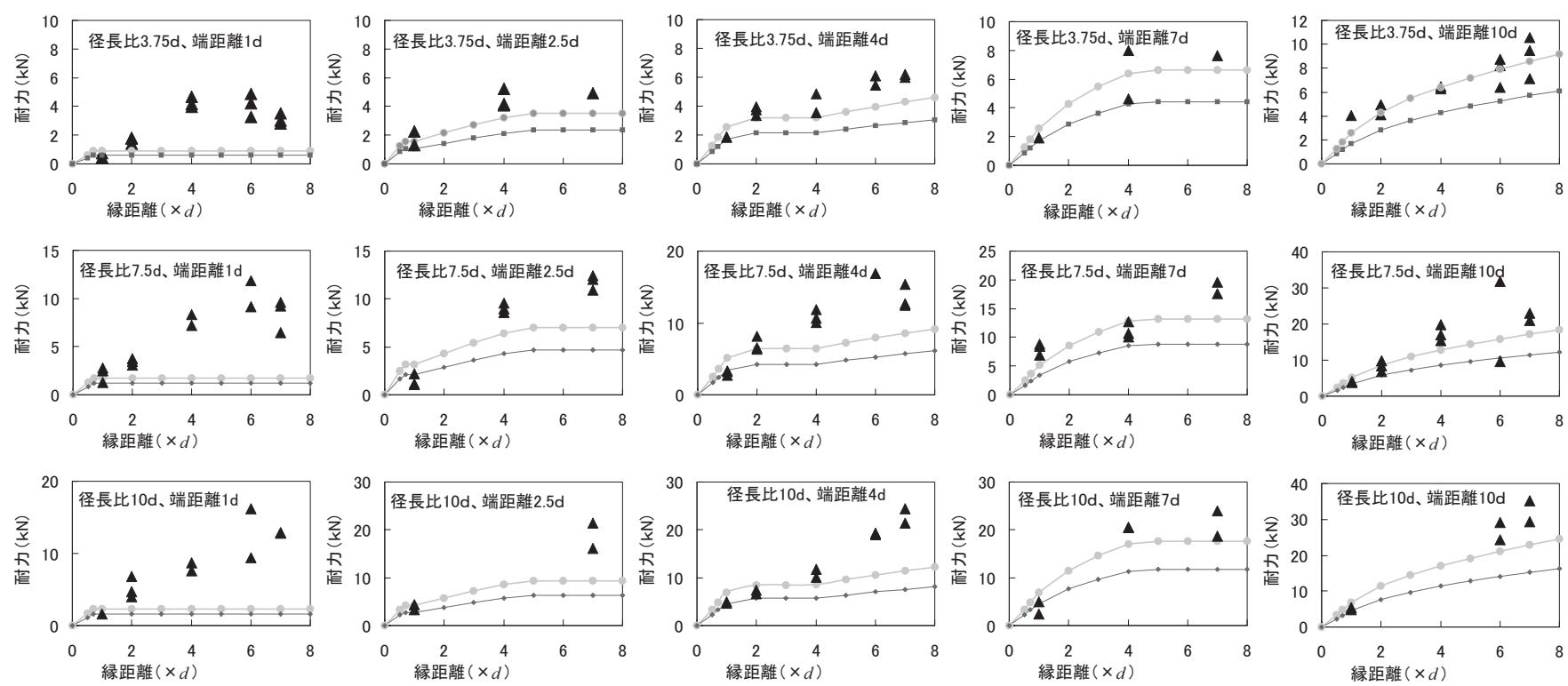

図 11 横軸を端距離としてまとめなおした実験結果と提案算定式の計算値

ただし、、 : 実験值、上側の線 : 算定值、下側の線 : 算定值の $2 / 3$

の実験值と算定值の比較を示す。これをみると、ばらつきが大きく ばらつき係数として $2 / 3$ を採用すればばらつきをとらえる事が出来 ると考えられる。そこで、本提案算定式での適応範囲は、縁距離は $2.5 d$ から $10 d$ 、端距離は $2 d$ から $7 d$ 、樹種はスギ、ボルト径が $16 \mathrm{~mm}$ である。今後、樹種およびボルト径は、実験による検証で幅が広が ると考えられるが、縁距離と端距離は極端に小さい $1 \mathrm{~d}$ は、適応範囲 から外すほうが良いと本実験での比較から考えた。

\section{6. まとめ}

木質構造では、破壊は木材の割裂でおこることが多い。しかし、 割裂強度はまだ解明されたとは言いがたい。本論文では、縁距離・ 端距離・径長比をパラメータとした木質ボルト接合単体（繊維直角 方向加力）の割裂破壞を主とした破壊強度算定式を提案した。
(提案式)

$$
\begin{gathered}
P=\min \left(P_{1}, \quad P_{3}, \quad \max \left(\min \left(P_{2}, \quad P_{4}\right), \quad 0.5 P_{l}\right)\right) \ldots(13) \\
P_{1}=2 t \sqrt{1.67 G_{c} G e_{a e}} \quad P_{2}=\frac{2 t e_{a h}^{2} \sigma_{90}}{3 e_{h}+1.5 d} \quad P_{3}=2 e_{a h} t \sigma_{90} \quad P_{4}=2 e_{a h} t \tau
\end{gathered}
$$

ただし、 $\rho$ : 密度、 $G$ : せん断弾性係数、 $\sigma_{90}$ : 横引っ張り強度、 $\tau$ : せん断強度、 $e_{e}$ : 縁距離、 $e_{h}$ : 端距離、 $t$ : 材幅、 $e_{a e}$ : 縁あき、 $e_{a h}$ : 端あき

現時点での適応範囲は、実験によりその妥当性が確認した、M16 のボルトで縁距離 $(1 d, 2 d, 4 d, 6 d, 7 d)$ ・端距離 $(1 d, 2.5 d, 4 d, 7 d$, $10 d)$ ・径長比 $(3.75 d, 7.5 d, 10 d)$ の範囲である。今後、適応範囲拡 大のために、異なる樹種およびボルト径の実験結果による妥当性検 証で必要である。 

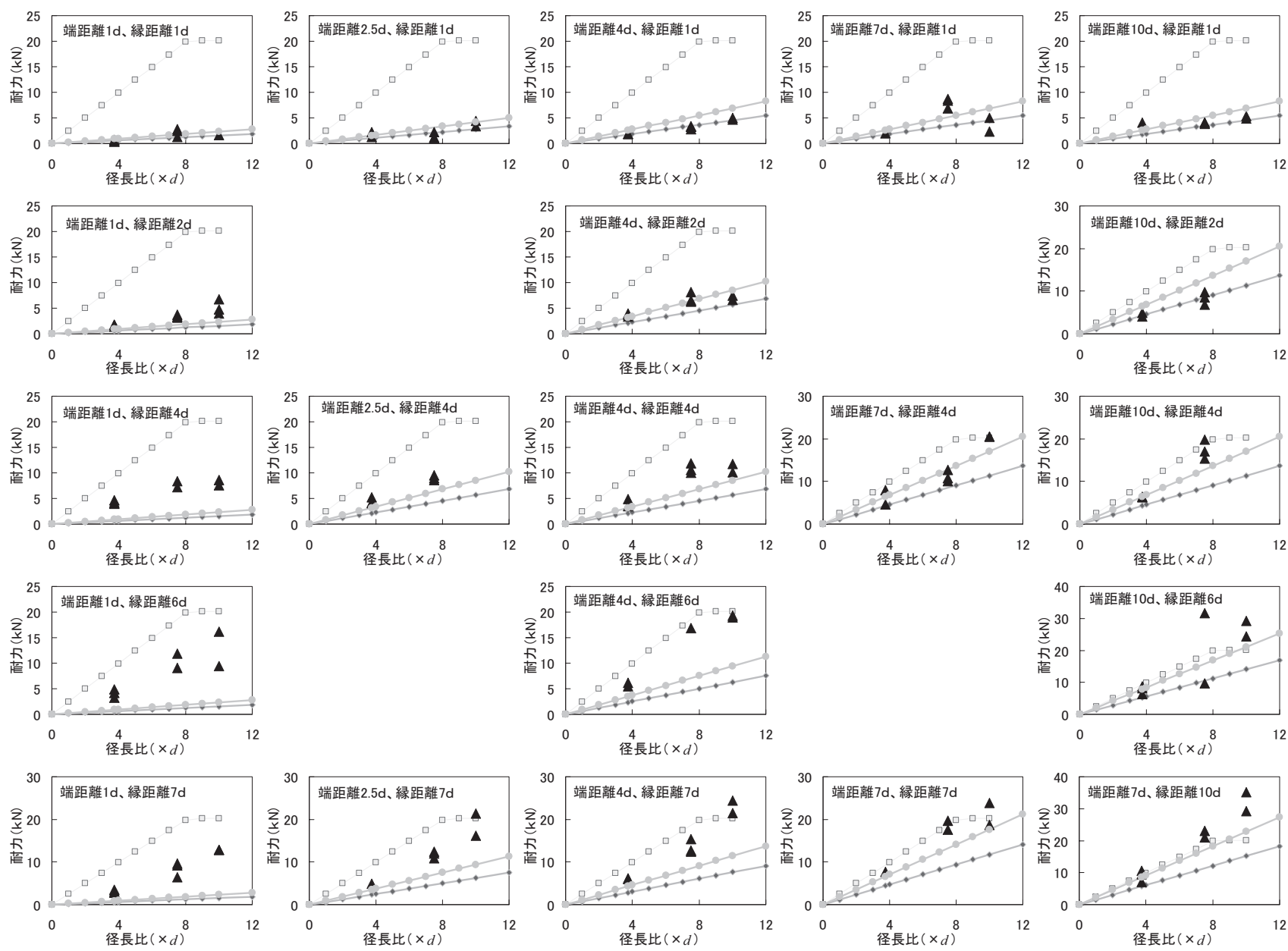

図 12 横軸を径長比としてまとめなおした実験結果と提案算定式の計算值

ただし、ム：実験值、 $\square$ : EYT 算定值、上側：算定值、下側：算定值の $2 / 3$

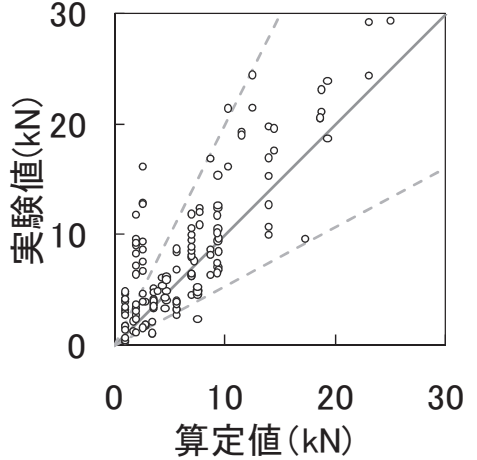

(a) 実験でのすべての条件

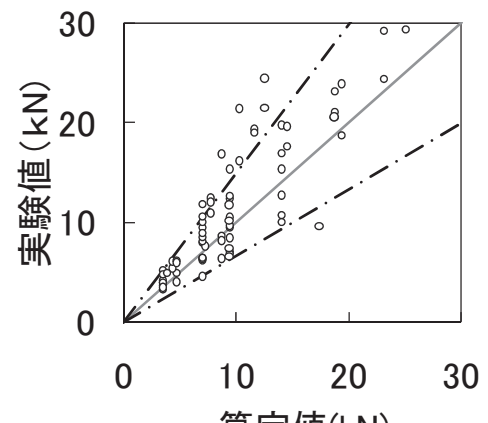

算定値 $(\mathrm{kN})$

（b）実験で端距離及び縁距離が $1 \mathrm{~d}$ の場合を除いた条件 図 13 実験值と算定值の比較
謝 辞

本研究を行うにあたって、工学院大学学術フロンテ ィア（宮澤健二代表）及び東京工業大学統合研究院（和 田章代表）の援助を受けた。ここに謝意を示す。

\section{参考文献}

1) 日本建築学会: 木質構造設計規準、丸善、東京、2006

2)van der Put $ら$ : Evaluation of perpendicular to grain failure of beams caused by concentrated loads of joints. Proc. of CIB-W18 Paper 33-7-7,2000

3)A.J.M. Leijten : Splitting Strength of Beams Loaded by Connections, Model Comparison, Proc. of CIB-W18 Paper, $35-7-7,2002$

4)J. L. Jensen: Splitting strength of beams loaded perpendicular to grain by dowel joints、Vol. 51, (5)、pp.480-485、2005

5 )安村基ら:繊維直交方向加力を受ける木質構造ボル卜接合部 に打ける破壞荷重推定法、日本建築学会学術講演梗概集.C-1, 構造 III, ,pp.65-66, 2006

6) 安村基ら : 繊維直交方向加力を受ける木質ボル卜接合部の破 壊機構、木材学会誌、42(3)、pp.225-233

7) H Petersson: On Design Criteria for Tension Perpendicular to Grain, Proc. of CIB-W18 Paper, 25-6-4, 1992

8) P J Gustafsson: A Study of Strength of Notched Beams, Proc of CIB-W18 Paper, 21-10-1, 1988

9) Trayer, G.W.: The Bearing Strength of Wood Under Bolts, Technical Bulletin No. 332. USDA Washington D.C. 1932

（2008年 3 月 10 日原稿受理，2009年 3 月 2 日採用決定） 